\title{
The characteristics and subtypes of headache in relation to age and gender in a rural community in Eastern Turkey
}

\author{
Türkiye'nin doğu ve kursal kesiminde yaşa ve cinsiyete göre baş ağrusı \\ özellikleri ve alt tipleri
}

Gülçin BENBIR, Derya KARADENIZ, Baki GÖKSAN

\begin{abstract}
Summary
Objectives: Headache is a frequent and widespread symptom constituting a major health problem for all age groups, though vast differences are present according to age and gender, as well as population characteristics. In this hospital-based study, we investigated the characteristics and subtypes of headache in relation to age and gender in a rural community in the eastern part of Turkey.

Methods: A total of 11549 subjects were evaluated, and 4951 patients (42.8\%) reported headaches. The 1-year headache prevalence was $38.6 \%$ in children, $47.0 \%$ in adults, and $23.3 \%$ in the elderly $(p<0.001)$. The female to male ratio was higher in adults $(\mathrm{p}<0.001)$ and elderly headache patients $(\mathrm{p}<0.001)$, but not in children $(\mathrm{p}=0.654)$.

Results: The most common diagnosis was frequent episodic tension-type headache in all age groups. Headaches attributed to epileptic seizure and rhinosinusitis were about three times more common in children, while chronic tension-type headache was about three times more common in adults and the elderly. While $60 \%$ of patients with migraine were male among the group of children, about $80 \%$ of patients were females among the adults.

Conclusion: The understanding of the epidemiology of headache and subtypes is important as it constitutes a major health problem due to its high prevalence in all age groups.

Key words: Headache; prevalence; subtypes.
\end{abstract}

\section{Özet}

Amaç: Baş ağrisı tüm yaş gruplarında sik görülen yaygın bir halk sağlığı problemi olmakla birlikte, yaşa, cinsiyete ve toplum özelliklerine göre farklilık göstermektedir. Bu hastane bazlı çalışmada, Türkiyénin kırsal bir bölümünde baş ağrısının özellikleri ve alt tipleri cinsiyete ve yaşa göre incelendi.

Gereç ve Yöntem: Toplam 11549 hasta değerlendirildi ve 4951 hastada (\%42.8) baş ağrısı saptandı. Bir yıllik baş ağrıst prevalansı çocuklarda \%38.6, erişkinlerde \%47.0 ve yaşl nüfusta ise \%23.3 olarak izlendi $(p<0.001)$.

Bulgular: Erişkinlerde ve ileri yaşlı hastalarda kadın erkek oranı yüksek olarak saptandı ( $p<0.001)$, çocuklarda ise kadın erkek oranı arasında farklılı izlenmedi ( $p=0.654$ ). Tüm yaş gruplarında en sık tanı sık epizodik gerilimi tipi baş ağrısı olarak izlendi. Epileptik nöbetlere ve rinosinüzite bağlı baş ağrıları çocuk yaş grubunda üç kat daba sık olarak görülürken, kronik gerilim tipi başağrısı erişkinlerde ve ileri yaş grubunda üç kat daha sık olarak saptandı. Çocuk yaş grubunda migren hastalarının \%60’ erkek iken, erişkin migren hastalarının \%80'i kadın idi.

Sonuç: Başăgrısının ve alt tiplerinin epidemiyolojisinin bilinmesi, tüm yaş gruplarında yüksek bir prevalansa sabip olmast ve büyük bir halk sağllğı sorunu oluşturması nedeniyle önemlidir.

Anahtar sözcükler: Baş ağrıs; prevalans; alt tipler. 


\section{Introduction}

Headache is a very common universal symptom with heterogeneous causes. ${ }^{[1]}$ There are numerous number of studies of population-based epidemiological studies about headache carried out in many countries. Several studies have reported a high incidence, prevalence, and individual and societal cost of headache disorders in children and adolescents, as well. ${ }^{[2]}$ The episodic and chronic daily headaches in children result in missed school days and interfering with other daily activities. ${ }^{[2,3]}$ It is well-known that childhood headache has specific characteristics other than adulthood headache. Nevertheless, epidemiological studies have demonstrated the reliability of the International Headache Society (IHS) criteria for the diagnosis of headache in children. ${ }^{[4,5]}$ The incidence of most primary headache disorders show a decline, especially after 55-60 years of age. ${ }^{[4,6]}$ In studies investigating adult patients over 18 years, headache patients over 65 years were reported to account for about $6.4 \%$ of the population and only few numbers of clinical and epidemiological studies have been performed in patients aged over 65 years. ${ }^{[7,8]}$

Headache is a frequent and widespread symptom constituting a major health problem at all age groups, though there are vast differences according to age and gender, as well as population characteristics. The primary headache subtypes in Turkish population has been little studied, there is only few studies evaluating the headache, and mostly in schoolchildren. ${ }^{[9-13]}$ Therefore, little is still known about the characteristics and subtypes of headache, especially in rural areas of Turkey.

In this context, we aimed to investigate the characteristics and subtypes of headache in relation to age and gender in a rural community in east Turkey.

\section{Methods}

This study was conducted in city of Igdir situated on the eastern border of Turkey. Igdir has international borders to three countries: Armenia, Republic of Azerbaijan, and Iran. It is an underdeveloped small city with a population of 181866 . About $41 \%$ of the population is between $0-14$ years of age, $54 \%$ of the population is aged between 15-64, and 5\% con- stitutes people aged 65 and more. The male gender constitutes $50.9 \%$ of the population, while $49.1 \%$ of Igdir population is female. This area is unique in that it includes three ethnical groups, Turkish, Kurdish and Azerian. More than 95\% of the population was Muslim.

Igdir State Hospital is the only hospital in Igdir. During one-year period of 2009, all patients admitted to Neurology outpatient clinics were involved in the study and evaluated by the same neurologist (G.B.). In Igdir, there is no family practitioner, and the State Hospital gives both primary- and secondarylevel service. The final diagnosis was made according to IHS-Second Edition of International Classification of Headache Disorders (ICHD-II) criteria ${ }^{[14]}$ on the basis of clinical assessment of the patients, and parents of children. In this study, all patients (with a participation rate of $100 \%$ ) were asked retrospectively about having had headache during the last year, and if so, they were evaluated in detail for headache. This cross-sectional, observational study has a sample size of 11549 people admitting to hospital and 4951 patients with headache in a city with a population of 181866 . The study was approved by local ethical committee.

The data was analyzed using the SPSS 12.0 software (SPSS Inc., Chicago, IL, USA). The 1-year prevalence rates were calculated overall and by demographics. Age was divided into 3 categories as follows: children and adolescents aged between 0 to 14 , adults aged between 15-64, and elderly aged 65 and more. In the statistical analysis, the chi-square test was used to compare the distribution of categorical variables between subgroups and the Student $t$ test was used to compare continuous variables. The threshold of significance was determined at a p value equal to or less than 0.05 .

\section{Results}

Among 11549 subjects admitted to neurology clinics and questioned for headache by the same neurologist, a total of 4951 patients (42.8\%) were diagnosed to have headache. Of 4951 subjects, 3178 patients $(64.1 \%$ of patients with headache, and $27.5 \%$ of all study population) had headache as the primary symptom to consult a neurologist. 
In the study population, 5002 subjects were male (43.3\%), and 6547 were female (56.7\%); while of 4951 patients with headache, 1442 patients (29.1\%) were male, and 3509 patients (70.9\%) were female $(\mathrm{p}<0.001)$. The mean age of the study population was $40.2 \pm 18.2$ years; and the mean age of the patients with headache was $38.5 \pm 17.5$ years (ranging between 5 and 94 years) ( $\mathrm{p}=0.856)$. The study population was divided into three groups on the basis of age distribution. Of 11549 subjects, 728 patients were equal to or younger than 14 years of age (children and adolescents), and 281 of them had headache (38.6\%). 9067 subjects were between 15 and 64 years of age (adults), and 4262 of them had headache (47.0\%). Finally, 1754 subjects were equal to or older than 65 years of age (elderly), and 408 of them had headache $(23.3 \%)$. The 1-year prevalence of headache was significantly lowest in elderly $(\mathrm{p}<0.001)$, and highest in adults $(\mathrm{p}=0.030)$. The 1-year prevalence rates for subtypes of headache in different age group are given in Table 1.

In children and adolescents with headache, the mean age was $12.0 \pm 1.7$ years. Among them, 132 patients (47.0\%) were male, and $149(53.0 \%)$ were female. The headache subtypes are given in Table 1. The most common diagnosis was frequent episodic tension-type headache (71.5\%), followed by headache attributed to rhinosinusitis (8.9\%), and migraine without aura (5.3\%). Of 15 patients with migraine, $60 \%$ were male and $40 \%$ were female. The type of headache did not show any relation with gender $(p=0.542)$ nor ages of the patients $(p=0.948)$ in this group (Figure 1). There was no difference between headache prevalences or subtypes with three ethnic groups, either.

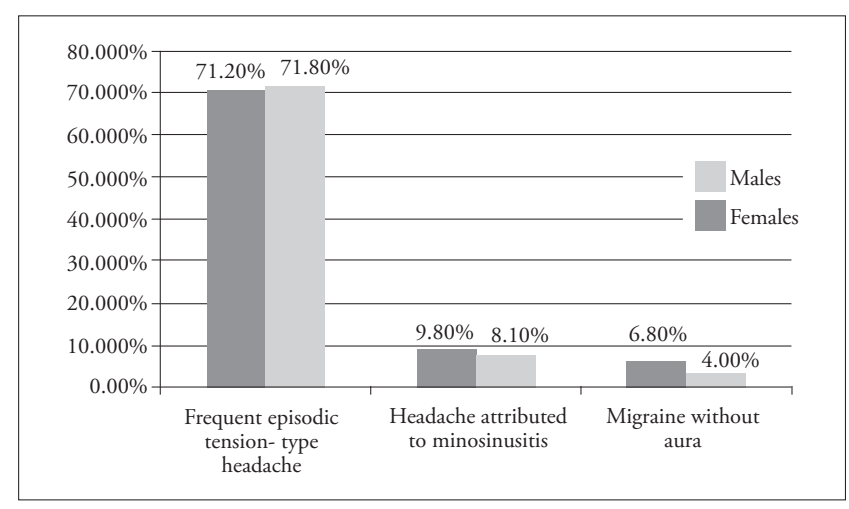

Figure 1. Common headache subtypes according to gender diagnosed in children and adolescents.
In adult headache patients, there was 4262 patients with a mean age of $36.9 \pm 13.6$ years. Of these, 1185 patients (27.8\%) were male, and 3077 patients $(72.2 \%)$ were female. There was a much wide range of headache subtypes in adults (Table 1). The most common diagnosis was frequent episodic tensiontype headache (63.6\%), followed by migraine without aura $(9.5 \%)$, and chronic tension-type headache (6.5\%). The type of headache showed a significant difference between males and females in this group $(\mathrm{p}<0.001)$. Although the most common two headache subtypes were frequent episodic tension-type headache and migraine without aura in both genders, the significant difference was due to rare causes of headache. The migraine without aura alone or in association with infrequent episodic tension-type headache, and headache attributed to major depressive disorder were two times; chronic migraine and headache attributed to somatisation disorder were three times; and typical aura with migraine headache and headache attributed to arterial hypertension were four times more commonly diagnosed in females. Whereas headache attributed to rhinosinusitis and to generalized anxiety disorder were two times more commonly encountered in males (Figure 2). The relationship between age and headache subtypes was also found to be significant $(\mathrm{p}<0.001)$. The headache subtypes did not show any difference in different ethnic groups ( $\mathrm{p}=0.694)$.

In elderly with headache, the mean age of 408 patients was $73.7 \pm 6.1$ years. There was 125 males (30.6\%) and 283 females (69.4\%). The most common headache subtype observed in this age group was similarly frequent episodic tension-type headache (68.4\%) (Table 1). The relationship between headache subtypes and gender was significant

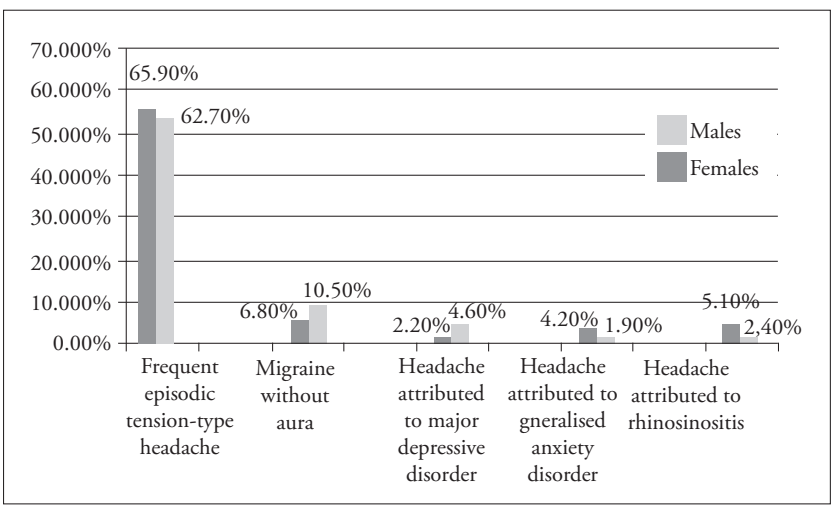

Figure 2. Common headache subtypes according to gender diagnosed in adults. 


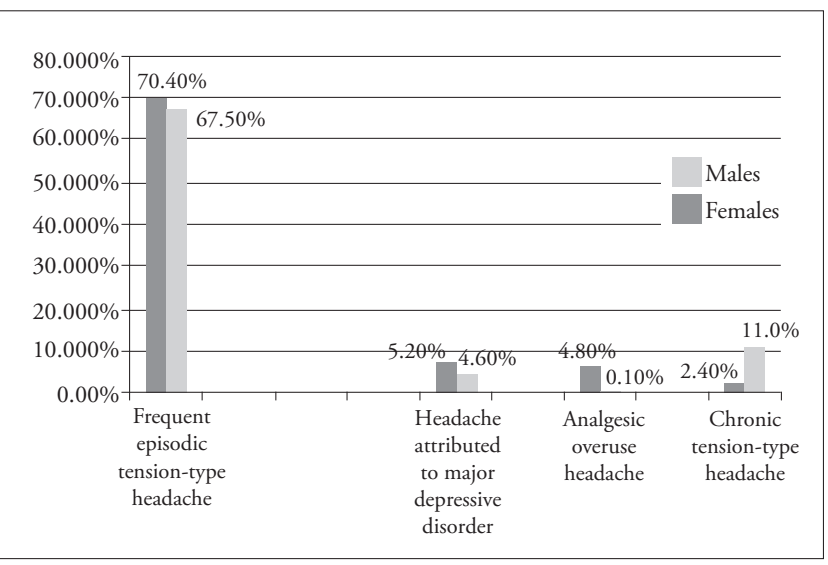

Figure 3. Common headache subtypes according to gender diagnosed in elderly.

$(\mathrm{p}=0.025$, OR 1.2). Although frequent episodic tension-type headache was the most common headache type in both genders, headache attributed to major depressive disorder and infrequent episodic tension-type headache were two times, and analgesic-overuse headache was about four times more common in males; whereas chronic tension-type headache was four times more common in females (Figure 3). The subtypes of headache showed no difference with age $(\mathrm{p}=0.599)$ or ethnicity $(\mathrm{p}=847)$ within this group of patients.

Finally, we observed that the female to male ratio was significantly higher in adults $(\mathrm{p}<0.001)$ and in elderly $(\mathrm{p}<0.001)$ but not in children and adolescents $(\mathrm{p}=0.654)$. The difference in headache subtypes among three age groups were also significantly different $(\mathrm{p}<0.001)$. The widest spectrum of subtypes was presented by adult age group. The headache attributed to epileptic seizure and to rhinosinusitis were about three times more commonly diagnosed in children and adolescents, while chronic tensiontype headache was about three times more common in adults and elderly.

\section{Discussion}

In the current study, the 1-year prevalence rates for headache and subtypes were investigated in different age groups in relation to gender, in a setting of Neurology clinics of a rural community in eastern Turkey. The 1-year prevalence in children and adolescent age group was found as $38.6 \%$. The most common diagnosis was frequent episodic tensiontype headache $(71.5 \%$ of all headaches with a 1 -year prevalence of $27.6 \%$ ), followed by headache attributed to rhinosinusitis $(8.9 \%$ of all headaches with a 1 -year prevalence of $3.43 \%$ ), and migraine without aura $(5.3 \%$ of all headaches with a 1 -year prevalence of $2.06 \%$ ). Alp et al. ${ }^{[13]}$ recently reported the one-year prevalence of headache subtypes as $14.3 \%$ for migraine, $8.6 \%$ for pure tension-type headache, and $4.6 \%$ for migraine plus tension-type headache. Bugdayci et al ${ }^{[9]}$ found the prevalence of recurrent headache as $49.2 \%$ in children attending to school aged between 8-16 years; and the most common diagnosis was tension-type headache with a ratio of $24.7 \%$ followed by migraine (unclassified) with a ratio of $10.4 \%$. A study investigating the epidemiologic profile of migraine and chronic daily headaches in students aged between 12 and 16 years in three public schools in Taiwan. Fuh et al., ${ }^{[15]}$ reported that 484 students $(12.2 \%)$ had migraine with or without aura, and 1092 students (27.6\%) had tension-type headaches. Heinrich et al. ${ }^{[16]}$ estimated the prevalence rates of primary headaches in children between 9-14 years in southern Germany as $17.6 \%$ for tension-type headache, $13.1 \%$ for migraine, while $35.5 \%$ of all children were reported that could not be classified. Medical Conditions Section of the National Health and Nutrition Examination Surveys reported the frequent or severe headache prevalence in children between 4-18 years of age as $17.1 \% .{ }^{[17]}$ In spite of some differences, the most common diagnosis is tension-type headache in almost all studies, followed by migraine. In our study, we also observed that headache attributed to rhinosinusitis is a common problem in this age group.

In adults, the 1-year prevalence of headache was $47.0 \%$ in our study. The most common diagnosis was also frequent episodic tension-type headache (63.6\% of all headaches with a 1-year prevalence of $29.9 \%)$, followed by migraine without aura $(9.5 \%$ of all headaches with a 1-year prevalence of $4.44 \%$ ), and chronic tension-type headache $(6.5 \%$ of all headaches with a 1-year prevalence of 3.07\%). In a study by Rueda-Sánchez et al. ${ }^{[18]}$ in Colombia, a survey was conducted in 1841 households aged between 18-65 years, which reported that $58 \%$ of participants had a headache episode at least once during their lifetime, with $13.7 \%$ describing the clinical characteristics of migraine, and $8.4 \%$ describing chronic daily headache. In a study by Al- 


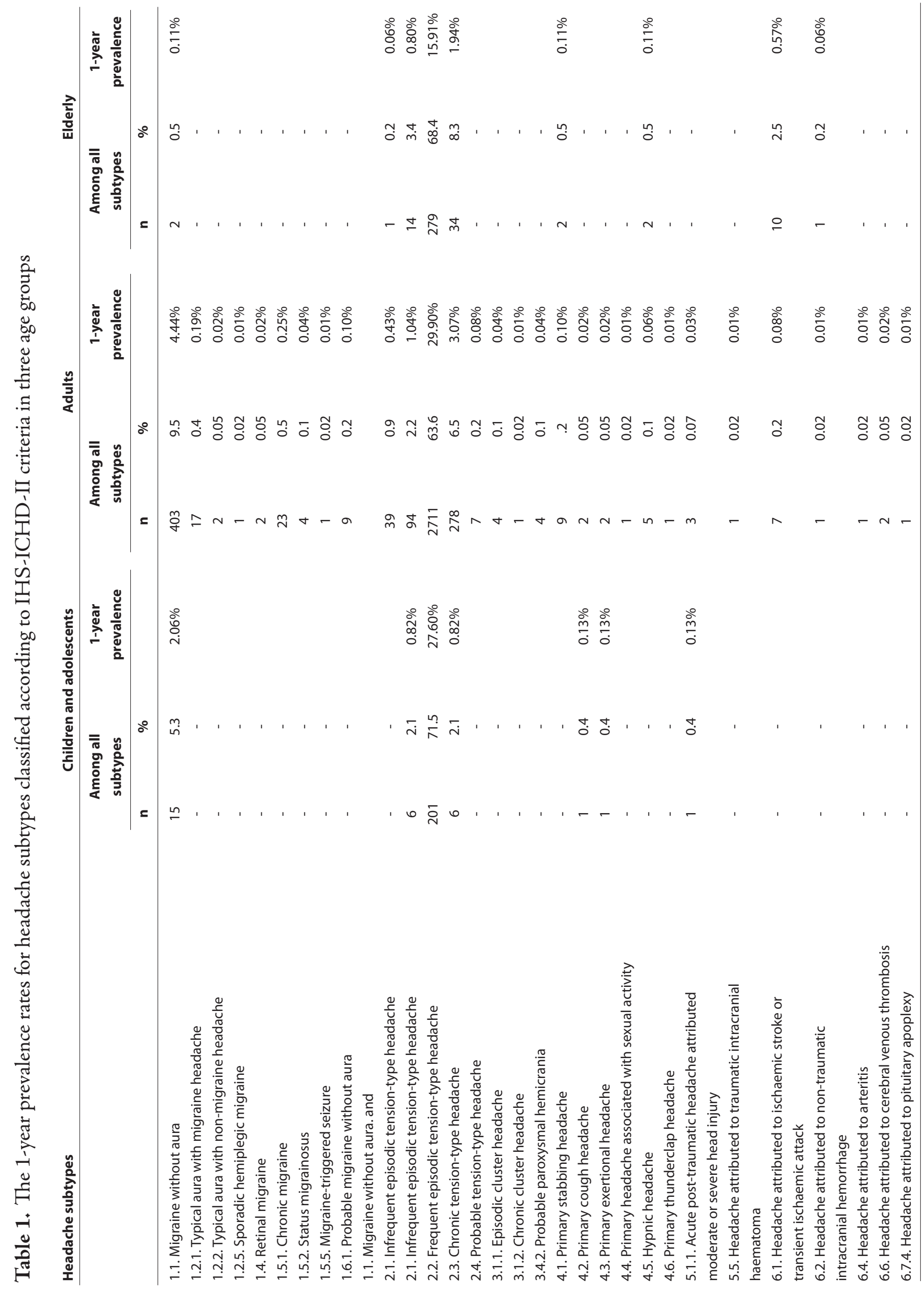




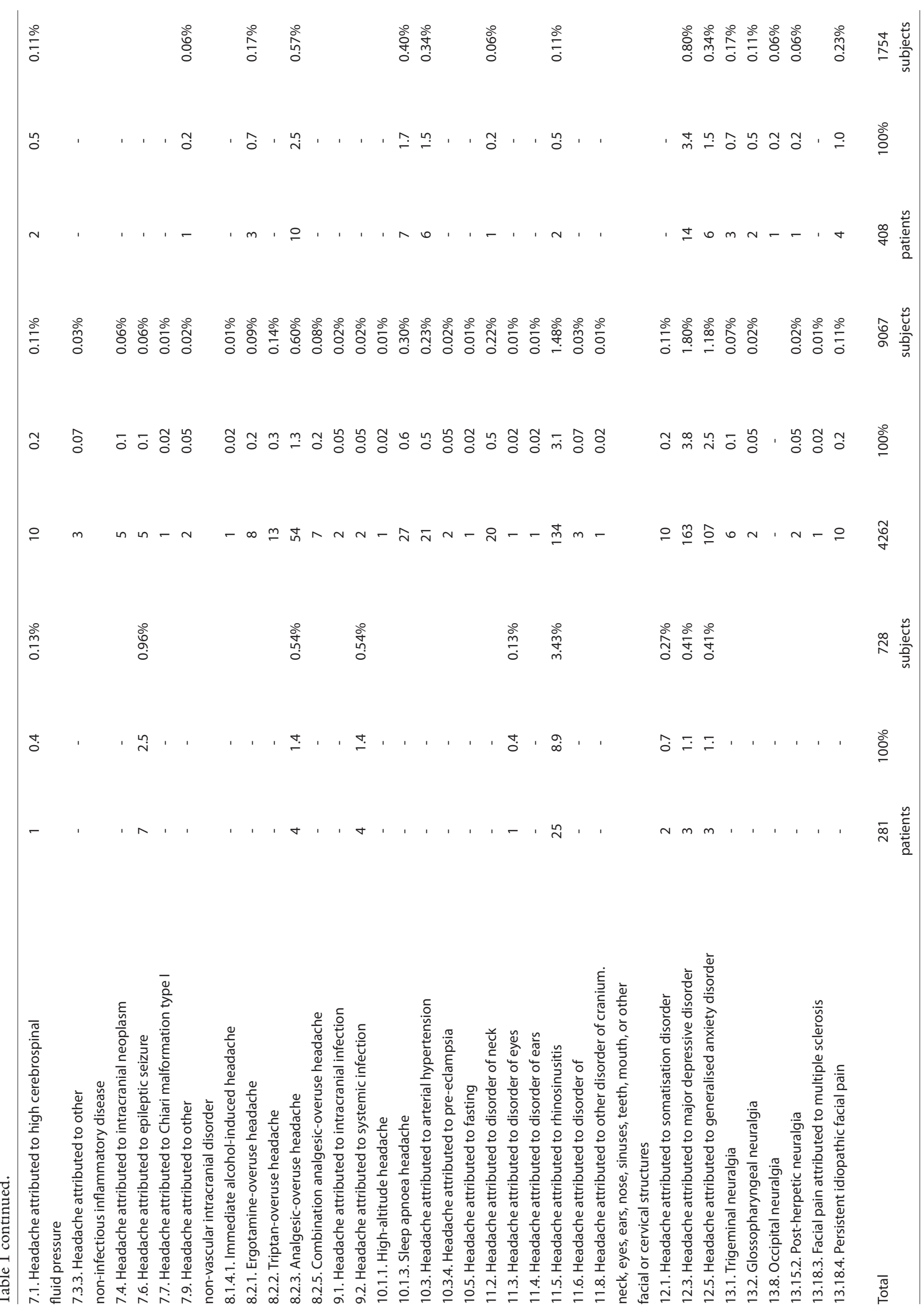


zoubi et al. ${ }^{[19]}$ investigating the adult and elderly age group, the majority of patients with headache could not be subtyped (38.4\%), though the most common diagnosis was tension-type headache (36.1\%). Another recent study by Vukovic et al. ${ }^{[20]}$ showed that the 1-year crude prevalence of migraine with and without aura was $7.5 \%$, of probable migraine was $11.3 \%$, and of tension-type headache was $21.2 \%$ in a study group aged 18 years and older. Stovner and Andree ${ }^{[21]}$ reported a mean prevalence of current migraine among more than 170,000 adults as $14.7 \%$, and the mean prevalence of tension-type headache among more than 66,000 adults as $62.6 \%$ in their recent review, similar to our results.

Almost all studies investigating the headache prevalences have examined a population aged 18 and over, but did not classify as adults and elderly. In our study, the 1-year prevalence of headache was found as $23.3 \%$ in elderly, and the most common headache subtype was similarly frequent episodic tension-type headache $(68.4 \%$ of all headaches with a 1 -year prevalence of $15.91 \%)$. Few studies in elderly population have reported around $43 \%$ to $66 \%$ for the one-year prevalence of headache. ${ }^{[22-24]}$ These authors also reported that the prevalence of headache was higher in women with a ratio of $52.0 \%$ versus $31.1 \%$ in men. Similarly, our findings showed that females had a higher prevalence rates for headache in adult and elderly groups, though this was not valid in children age group.

Unlike common headache types, studies investigating the prevalence rates for such rare headache subtypes are rare. Our study also supplies the 1-year prevalence rates for other rare subtypes of headache in different age groups (Table 1). Katsarava et al. ${ }^{[25]}$ reported the prevalence of cluster headache as $87 / 100000$, which was found as $44 / 100000$ for episodic and 11/100000 for chronic cluster headache in our study. Koopman et al. ${ }^{[26]}$ estimated the incidence rate for trigeminal neuralgia as $12.6 \%$. The 1-year prevalence for trigeminal neuralgia was found as $0.07 \%$ in adults and $0.17 \%$ in elderly in our study.

In addition, we also observed the developmental pattern in gender difference for migraine. While $60 \%$ of patients with migraine were male in young age group, about $80 \%$ of the patients with the diagnosis of migraine were females in adults. A similar observation was recently reported by Slater et al., ${ }^{[27]}$ who suggested that biological or sociological factors increase the risk of migraine in boys in the preadolescent period, which shifts as children enter adolescence. On the other hand, the subtypes of headache showed no significant difference in relation with gender in children and adolescents. Among three age groups, the headache attributed to rhinosinusitis and to epileptic seizure were about three times more commonly diagnosed in children and adolescents, while chronic tension-type headache was about three times more common in adults and elderly. Unlike children and adolescents, the female to male ratio was significantly higher in adults and elderly. In adults, the migraine without aura alone or in association with infrequent episodic tension-type headache, and headache attributed to major depressive disorder were two times; chronic migraine and headache attributed to somatisation disorder were three times; and typical aura with migraine headache and headache attributed to arterial hypertension were four times more commonly diagnosed in females. On the other hand, headaches attributed to rhinosinusitis and to generalized anxiety disorder were two times more commonly encountered in males. In elderly, headache attributed to major depressive disorder, infrequent episodic tensiontype headache, and analgesic-overuse headache were two times more common in males, whereas chronic tension-type headache was four times more common in females.

\section{References}

1. Stovner Lj, Hagen K, Jensen R, Katsarava Z, Lipton R, Scher $A$, et al. The global burden of headache: a documentation of headache prevalence and disability worldwide. Cephalalgia 2007;27(3):193-210.

2. Hämäläinen ML, Hoppu K, Santavuori P. Pain and disability in migraine or other recurrent headache as reported by children. Eur J Neurol 1996;3(6):528-32.

3. Annequin $D$, Tourniaire $B$, Massiou $H$. Migraine and headache in childhood and adolescence. Pediatr Clin North Am 2000;47(3):617-31.

4. Lipton RB, Stewart WF, Merikangas KR. Reliability in headache diagnosis. Cephalalgia 1993;13 Suppl 12:29-33.

5. Winner P, Martinez W, Mate L, Bello L. Classification of pediatric migraine: proposed revisions to the IHS criteria. Headache 1995;35(7):407-10.

6. Tanganelli P. Secondary headaches in the elderly. Neurol Sci 2010;31 Suppl 1:S73-6. 
7. Solomon S, Cappa KG. The headache of temporal arteritis. J Am Geriatr Soc 1987;35(2):163-5.

8. Lisotto C, Mainardi F, Maggioni F, Zanchin G. Headache in Sturge-Weber syndrome: a case report and review of the literature. Cephalalgia 2004;24(11):1001-4.

9. Bugdayci R, Ozge A, Sasmaz T, Kurt AO, Kaleagasi H, Karakelle $A$, et al. Prevalence and factors affecting headache in Turkish schoolchildren. Pediatr Int 2005;47(3):316-22.

10. Ozge $C$, Atiş $S$, Ozge A, Nass Duce $M$, Saraçoğlu M, Saritaş $E$. Cough headache: frequency, characteristics and the relationship with the characteristics of cough. Eur J Pain 2005;9(4):383-8.

11. Ozge A, Buğdayci R, Saşmaz T, Kaleağasi H, Kurt O, Karakelle $A$, et al. The linear trend of headache prevalence and some headache features in school children. Agri 2007;19(2):20-32.

12. Karli N, Bican A, Zarifoğlu M. Course of adolescent headache: 4-year annual face-to-face follow-up study. J Headache Pain 2010;11(4):327-34.

13. Alp R, Alp SI, Palanci Y, Sur H, Boru UT, Ozge A, et al. Use of the International Classification of Headache Disorders, Second Edition, criteria in the diagnosis of primary headache in schoolchildren: epidemiology study from eastern Turkey. Cephalalgia 2010;30(7):868-77.

14. Headache Classification Subcommittee of the International Headache Society. The International Classification of Headache Disorders: 2nd edition. Cephalalgia 2004;24 Suppl 1:9160.

15. Fuh JL, Wang SJ, Lu SR, Liao YC, Chen SP, Yang CY. Headache disability among adolescents: a student population-based study. Headache 2010;50(2):210-8.

16. Heinrich M, Morris L, Kröner-Herwig B. Self-report of headache in children and adolescents in Germany: possibilities and confines of questionnaire data for headache classification. Cephalalgia 2009;29(8):864-72.

17. Lateef TM, Merikangas KR, He J, Kalaydjian A, Khoromi S, Knight $E$, et al. Headache in a national sample of American children: prevalence and comorbidity. J Child Neurol
2009;24(5):536-43.

18. Rueda-Sánchez M, Díaz-Martínez LA. Prevalence and associated factors for episodic and chronic daily headache in the Colombian population. Cephalalgia 2008;28(3):216-25.

19. Alzoubi KH, Mhaidat N, Azzam SA, Khader Y, Salem S, Issaifan $\mathrm{H}$, et al. Prevalence of migraine and tension-type headache among adults in Jordan. J Headache Pain 2009;10(4):26570.

20. Vuković V, Plavec D, Pavelin S, Janculjak D, Ivanković M, Demarin V. Prevalence of migraine, probable migraine and tension-type headache in the Croatian population. Neuroepidemiology 2010;35(1):59-65.

21. Stovner LJ, Andree C. Prevalence of headache in Europe: a review for the Eurolight project. J Headache Pain 2010;11(4):289-99.

22. Junior AS, Krymchantowski A, Moreira P, Vasconcelos L, Gomez R, Teixeira A. Prevalence of headache in the entire population of a small city in Brazil. Headache 2009;49(6):8959.

23. Corrêa Tdos S, Santos KM, Galato D. Prevalence and management of headache in a selected area of Southern Santa Catarina. Arq Neuropsiquiatr 2010;68(2):216-23.

24. Torelli P, Abrignani G, Berzieri L, Castellini P, Ferrante T, Lambru G, et al. Population-based pace study: lifetime and pastyear prevalence of headache in adults. Neurol Sci 2010;31 Suppl 1:S145-7.

25. Katsarava Z, Dzagnidze A, Kukava M, Mirvelashvili E, Djibuti $M$, Janelidze $M$, et al. Prevalence of cluster headache in the Republic of Georgia: results of a population-based study and methodological considerations. Cephalalgia 2009;29(9):94952.

26. Koopman JS, Dieleman JP, Huygen FJ, de Mos M, Martin CG, Sturkenboom MC. Incidence of facial pain in the general population. Pain 2009;147(1-3):122-7.

27. Slater S, Crawford MJ, Kabbouche MA, LeCates SL, Cherney $S$, Vaughan $P$, et al. Effects of gender and age on paediatric headache. Cephalalgia 2009;29(9):969-73. 